\title{
SPEGIFICTIIES OF TEACHING ENGLISH FOR BUSINESS AND ECONOMICS
}

\author{
Carina Ionela BRANZILA* \\ a) Alexandru Ioan Cuza University, Faculty of Economics and Business \\ Administration, Iași, Romania
}

Please cite this article as:

Article History:

Branzila, C.I., 2019. Specificities of teaching English for Received: 10 October 2019 Business and Economics. Review of Economic Studies Accepted: 4 November 2019 and Research Virgil Madgearu, 12(2), pp.5-13.

doi: 10.24193/RVM.2019.12.36.

\begin{abstract}
This article aims at discussing the specific character of Business English as compared to General English in general. It will refer to the particularities of Business English taught to undergraduate students in a Romanian university compared to teaching it in-company and in one to one courses, using real case studies. We will discuss the teaching approaches adapted to each of these courses, comparing and analyzing them in depth. The differences will be regarded from the vocabulary and methodological point of view. However, the teaching approach employed and discussed in this article is the communicative one - using mainly functional and task based activities. The article further looks into the recent research on Business English in order to discuss the directions in which this area of study is moving and to examine current issues concerning the field.
\end{abstract}

Key words: Business English; specific; teaching approach

JEL Classification: A1; $A 2 ; A 3 ; Y 8$

(C) 2019 Alma Mater Publishing House. All rights reserved.

* Corresponding author. E-mail address: carinabranzila@gmail.com. 


\section{References:}

1. Brieger, N. and Comfort, J., 1992. Language reference for business English: grammar, functions and communication skills. New York: Prentice Hall International.

2. Brieger, N., 1997. The York Associated teaching business English Handbook. York: York Assoc.

3. Ciortescu, R.E., 2012. Teaching Communication Skills in Business English Classes - an overview. International Journal of Communication Research, 3, p.219-223.

4. Mann, J., 2008. Introducing the CBEC. Paper presented at IETEFL BESIG Annual Conference, Bonn, 21st-23rd November. 